\title{
CZY CESARZ KONSTANTYN WIELKI ZABIEGAŁ O KOMPROMIS Z DONATYSTAMI?
}

Schizma do jakiej doszło w Kościele w Afryce Północnej na początku IV wieku, nazwana potem donatyzmem ${ }^{1}$, odegrała niezwykle ważną rolę w kształtowaniu się stosunków pomiędzy cesarstwem rzymskim a Kościołem powszechnym. Kiedy bowiem Konstantyn Wielki ogłosił, wraz z Licyniuszem, w roku 313 w Mediolanie tolerancję religijną ${ }^{2}$, dając w ten sposób początek nowej epoce w dziejach Kościoła i państwa ${ }^{3}$, jeszcze w tym samym roku, przyszło mu zająć się kwestią rozłamu istniejącego wśród chrześcijan afrykańskich. Konstantyn wciągnięty w wewnętrzne sprawy Kościoła przez swych doradców kościelnych, zaangażował się potem bardzo, ale już na prośbę samych donatystów ${ }^{4}$, w rozpatrzenie sporu, jaki wiedli ze swoimi przeciwnikami. Zażegnanie wspom-

${ }^{1}$ Literatura poświęcona donatyzmowi liczy już dziś bardzo wiele pozycji, wśród nich do najważniejszych należą: P. Monceaux, Histoire littéraire de l'Afrique Chrétienne depuis les origines jusqu'à l'invasion Arabe, t. 4: Le Donatisme, Paris 1912; t. 5: Saint Optat et les premiers écrivains donatistes, Paris 1920; t. 6: Littérature donatiste au temps de saint Augustin, Paris 1922; t. 7: Saint Augustin et le donatisme, Paris 1923; W. H. C. Frend, The Donatist Church. A Movement of Protest in Roman North Africa, Oxford 1952; zob. też wstęp Y. M. J. Congara do dzieł św. Augustyna skierowanych przeciwko donatystom w serii „Bibliothèque Augustinienne”, 28, Paris 1963, 9-124; E. L. Grasmück, Coercitio. Staat und Kirche im Donatistenstreit, Bonn 1964. Jako wprowadzenie może też posłużyć tekst F. Drączkowskiego, Donatyzm, EK IV 111-113.

${ }^{2}$ Pamiętać jednak trzeba, że tzw. edykt mediolański poprzedzony został tolerancyjnym edyktem cesarza Galeriusza z 311 roku; zob. Lactantius, De mortibus persecutorum 34; Eusebius, HE VIII 17, 3-10; Nicephorus, HE VII 23.

${ }^{3}$ Zwrot dokonany przez cesarza Konstantyna Wielkiego w polityce cesarstwa rzymskiego wobec Kościoła określa się często mianem ,,przełomu konstantyńskiego”. Polegał on nie tylko na wprowadzeniu tolerancji wobec chrześcijaństwa, a zatem uznaniu go za religię zgodną z obowiązującym porządkiem prawnym, ale i na stopniowym przekształceniu go w religię uprzywilejowaną; zob.J.Vogt, Upadek Rzymu, thum.A.Łukaszewicz, Warszawa 1993, 99-120; J.Gaudemet, La législation religieuse de Constantin, tegoż: Église et société en Occident au Moyen Age, London 1984, 26-48.

${ }^{4}$ Cesarz w swej korespondencji nie nazywał przeciwników Cecyliana, biskupa Kartaginy, donatystami, termin ten jest zdecydowanie późniejszy, jednak ułatwia on identyfikacje duchownych przynależnych do „Kościoła czystych”, i dlatego będę go używał. 
nianego konfliktu i przywrócenie pokoju w Kościele było niezwykle ważne z punktu widzenia cesarza. Brak jedności chrześcijan mógł ściągnąć na całą społeczność gniew Boży i zagrozić pomyślności cesarstwa, a w dodatku stanowił podatny grunt dla niepokojów społecznych ${ }^{5}$. Toteż władca wykazał dużą aktywność dążąc do zakończenia schizmy. Zorganizował w jej sprawie w roku 313 sąd biskupów galijskich pod przewodnictwem papieża Miltiadesa, przekształcony ostatecznie w synod rzymski z udziałem biskupów italskich. W roku zaś następnym zwołał znacznie liczniejszy synod w Arles, a potem nakazał swoim urzędnikom przeprowadzenie specjalnego śledztwa w Afryce w sprawie zarzutów wysuwanych przez donatystów, by wreszcie w roku 316 osobiście rozsądzić skłóconych w Mediolanie i wydać kolejny już wyrok. W końcu wobec oporu pars Donati Konstantyn zarządził represje skierowane przeciwko jej zwolennikom, aby po kilku latach z nich zrezygnować. Postawa cesarza może więc dziwić i nasuwać podejrzenia o brak zdecydowania, a nawet wręcz chwiejność. Powołując kolejno różne gremia do rozpatrzenia tej samej sprawy władca jakby przekreślał wyroki wydane wcześniej również na swoje polecenie.

Zdaniem W. H. C. Frenda Konstantyn był niezdecydowany, dlatego tak często zmieniał decyzje, raz będąc przychylnym cecylianom innym razem donatystom $^{6}$. Podobnie oceniali jego politykę P. Monceaux ${ }^{7}$, E. Stein ${ }^{8}$ czy R. MacMullen ${ }^{9}$ wskazując, iż cesarz wciąż się wahał. Według Ewy Wipszyckiej Konstantyn „od początku nie mial najmniejszej sympatii” dla donatystów, a decydował się na kolejne sądy, czy komisje rozpatrujące wysuwane przez nich zarzuty, bowiem szukał z nimi porozumienia, zdając sobie sprawę z ich siły. Cesarz dobrze wiedział, jej zdaniem, że nie jest wstanie dojść prawdy w sporach, jakie prowadzili między sobą duchowni w Afryce, ale „wykazał wiele gotowości rzetelnego poznania sprawy"10. Dlaczego zatem Konstantyn godził się na rozpatrywanie zarzutów donatystów wciąż na nowo? Czy może to dowodzić jego dążenia do poznania prawdy, do wyjaśnienia wszystkich zawiłości związanych ze wzajemnymi oskarżeniami, czy raczej świadczyć o jego wytrwałych zabiegach zmierzających do wypracowania kompromisu z donatystami?

5 Zachowanie chrześcijan w jedności było więc zasadniczym celem polityki kościelnej Konstantyna Wielkiego; zob. O. Nordeval, The Emperor Constantine and Arius: Unity in the Church and Unity in the Empire, „Studia Theologica” 42(1988) 113-150; R.H. Storch, The „Eusebian Constantine", ChH 40(1971) 151n.

${ }^{6}$ Por. Frend, The Donatist Church, 141-168.

${ }^{7}$ P. Monceaux (Le Donatisme, s. 30) określał politykę Konstantyna wobec donatystów jako „d'atermoiements et de ménagements”.

${ }^{8}$ Por. E. Stein, Histoire du Bas-Empire, t. 1: De l'État romain à l'État byzantin (284-476), Paris 1959,101

${ }_{9}$ Według R.MacMullena (Constantin. Le premier empereur chrétien, Paris 1971, 113) „quiconque retrace le cours de ces événements doit être frappé par l'irrésolution de l'empereur par contraste avec l'assurance et l'énergie qu'il avait montrées jusqu'alors dans d'autres activités".

${ }^{10}$ E.Wipszycka, Kościół w świecie późnego antyku, Warszawa 1994, 149-151. 
1. Donatyści. Podejmując próbę wyjaśnienia wskazanych kwestii trzeba przypomnieć kim byli donatyści i jaka była istota sporu, który wiedli z Cecylianem, biskupem Kartaginy. Geneza donatyzmu ${ }^{11}$ sięgała swymi korzeniami okresu wielkiego prześladowania chrześcijan, przeprowadzanego na rozkaz cesarzy Dioklecjana i Galeriusza ${ }^{12}$. Wtedy to część biskupów afrykańskich miała wydać Święte Księgi cesarskim urzędnikom zgodnie z pierwszym edyktem Dioklecjana przeciwko chrześcijanom ${ }^{13}$. W konsekwencji oskarżeni zostali o traditio, co traktowano jako zdradę wiary ${ }^{14}$. Takie właśnie zarzuty stawiano m.in. Mensuriuszowi, biskupowi Kartaginy, choć ten dowodzil, że wydał jedynie pisma heretyckie. Mensuriusz zwalczał fanatyczną postawę wśród chrześcijan szukających w swej nadgorliwości męczeństwa. Owym zwolennikom entuzjastycznej martyrologii, którym udało się przeżyć represje po tym, jak sami zadenuncjowali się przed funkcjonariuszami państwowymi, odmawiał prawa do miana wyznawców, wzmagając w ten sposób niechęć szerokich kręgów rygorystów do własnej osoby ${ }^{15}$. Kiedy po śmierci Mensuriusza jego dotychczasowi współpracownicy przeprowadzili na przełomie lat $311 / 312^{16}$ pośpieszny wybór Cecyliana, oddanego mu diakona, na biskupią stolicę Kartaginy, rygoryści nie chcieli tego „faktu dokonanego” zaakceptować ${ }^{17}$. Uniemożliwiono bowiem biskupom numidyjskim udział w wyborze ${ }^{18}$, a w dodatku jednego z trzech konsekratorów Cecyliana, Feliksa z Abtungi, oskarżali o zbrodnię traditio, której miał się dopuścić w okresie prześladowań Dioklecjana. Przeciw-

${ }^{11}$ Na temat genezy donatyzmu zob. T.D.Barnes, The Beginnings of Donatism, JTS 26(1975) $13-22$.

${ }^{12}$ P. Janiszewski, Galeriusz czy Dioklecjan? Kwestia odpowiedzialności za rozpoczęcie tzw. „wielkiego prześladowania” chrześcijan w 303 roku, „Meander” 48(1993), 303-317; G. E. M. de Ste Croix, Aspects of the „, Great” Persecution, „Harvard Theological Review” 47(1954), 74-113.

${ }^{13} \mathrm{O}$ treści tego edyktu wspomina w swej Historii Kościoła Euzebiusz z Cezarei ( HE VIII 2 , 4-5).

${ }^{14}$ Por. na ten temat: B. Kriegbaum, Kirche der Traditoren oder Kirche der Märtyrer? Die Vorgeschichte des Donatismus, Innsbruck -Wien 1986, 59-95.

15 Por. Monceaux, Le Donatisme, 9-15.

${ }^{16} \mathrm{Za}$ tą datą opowiada się J. L. Maier (Le dossier du donatisme, t. 1: De origines à la mort de Constance II (303-361), TU 134, Berlin 1987, 128-134); natomiast według T. D. Barnesa (The Beginnings of Donatism, s.18-20) miało to miejsce w roku 307, a B. Kriegbaum (Kirche der Traditoren, s. 130-134) plasuje je w latach 308-310/311.

17 Według Optata z Milewe (Contra Parmenianum I 18-19, CSEL 26, 19-21) opozycji przeciwko Cecylianowi w Kartaginie przewodzić miała wdowa Lucylla, zganiona niegdyś publicznie przez niego za całowanie przed komunią relikwii pseudomęczennika. To do niej przyłączyć się mieli Botrus i Celestiusz, diakoni Mensuriusza, niezadowoleni z wyboru Celestyna oraz prezbiterzy, których pieczy Mensuriusz miał powierzyć złoto i srebro będące własnością Kościoła kartagińskiego; por. Augustinus, Breviculus collationis cum donatistis III 13-14, „Bibliothèque augustinienne” 32, 192-198, a także Monceaux, Le Donatisme, s. 15-19.

${ }_{18}$ Nie zaczekano na przybycie prymasa Numidii, Sekundusa z Tigisi, mimo, że prymas Numidii zwyczajowo brał udział w wyświęcaniu biskupa Kartaginy; zob. Monceaux, Le Donatisme, s. $17-18$ 
nicy Cecyliana zorganizowali więc jeszcze w roku 312 synod złożony z siedemdziesięciu biskupów numidyjskich, na którym pod przewodnictwem Sekundusa z Tigisi orzeczono nieważność sakry Cecyliana i powołano w jego miejsce Majoryna $^{19}$. Fakt ten zapoczątkował schizmę w Kościele afrykańskim, choć Cecylian starał się temu zapobiec, zgłaszając gotowość do powtórzenia aktu swej konsekracji biskupiej ${ }^{20}$. Wkrótce po śmierci Majoryna jego następcą został Donat, dotychczasowy biskup Casae Nigrae, od imienia którego nazwano schizmatyków donatystami ${ }^{21}$.

Duchowni ci uważali się za społeczność świętych, Kościół czystych, który zachowywał swą tożsamość odrzucając ,,zepsuty” świat i wszelkie z nim kompromisy, dzięki czemu utrzymywał łączność z Bogiem i jedynie on mógł liczyć na wysłuchanie swoich modlitw. Donatyści żyli ideą ludu wybranego osaczonego przez „zło tego świata”, od którego chcieli się odciąć zwalczając wszystko to, co „nieczyste”. Szczególną odrazę żywili do traditores. W przekonaniu duchownych z pars Donati już sam fakt kontaktowania się z nimi, bądź z ich następcami wystarczał, aby stać się współwinnym, a wszystkie sakramenty udzielone lub otrzymane przez traditores traciły swą ważność. Byli oni uważani przez donatystów za schizmatyków, którzy mogli być przyjęci do prawdziwego Kościoła tylko po odbyciu stosownej pokuty i powtórnym chrzcie ${ }^{22}$. Dlatego też zwolennicy Donata nie chcieli znajdować się we wspólnocie z duchownymi utrzymującymi łączność z Feliksem i Cecylianem. Widzieli w nich bowiem „synów zdrajców”, których nieprawość zamieniła w anty-Kościół, „Kościół traditorów”, „Kościół Judasza”. Swój „niepokalany Kościól” wywodzili natomiast od męczenników ${ }^{23}$. Donatyści postrzegali zatem Kościół na sposób dualistyczny: dobrej wspólnocie wiernych towarzyszyła jej zła karykatura ${ }^{24}$.

2. Synod w Rzymie (313). Konstantyn poinformowany o rozwoju sytuacji w Kościele afrykańskim najprawdopodobniej przez Hozjusza, biskupa Kordo-

${ }^{19}$ Był on domownikiem Lucylli; por. Optatus Milevitanus, Contra Parmenianum I 19, CSEL 26,21

${ }^{20}$ Por. Monceaux, Le Donatisme, s.19. Sam fakt schizmy Optat z Milewe (Contra Parmenianum I 19, CSEL 26, 21) przedstawił w znamiennych słowach: ,altare contra altare erectum est et ordinatio inlicite celebrata est”.

${ }^{21}$ Por. T. G. Elliott, The Christianity of Constantine the Great, Scranton 1996, 80-82; Ch. Pietri, L'échec de l'unité ,impériale” en Afrique. La résistance donatiste (jusqu'en 361), w: Histoire du Christianisme, t. 2: Naissance d'une chrétienté (250-430), Paris 1995, 229-233.

22 Por. W. H. C. Frend, The Donatist Church, s. 1-24; H. I. Marrou, L'Église de l'Antiquité tardive 30-604, Paris 1985, 31-32; E. Wipszycka, Kościót w świecie późnego antyku, s. 145-146; P. Brown, Augustyn z Hippony, thum. W. Radwański, Warszawa 1993, 210-225.

23 P. Maraval (Le Christianisme de Constantin à la conquête arabe. Paris 1997, 299) podkreśla, że w ich przekonaniu „la véritable Église souffre toujours persécution”.

${ }^{24} \mathrm{Na}$ temat podobnych tradycji pojmowania społeczności religijnej zob. W. H. C. Frend, Martyrdom and Persecution in the Early Church, Oxford 1964, 61. 
by, swego doradcę w sprawach kościelnych, powierzył mu jakieś ważkie zadania w sprawie schizmy. Być może wysłał go nawet do Afryki, aby podjął próbę zażegnania konfliktu, a przynajmniej lepiej rozpoznał sytuację ${ }^{25}$. Pewne jest, że władca, po uzyskaniu stosownych informacji, opowiedział się zdecydowanie po stronie Cecyliana, polecając wypłacić na jego ręce trzy tysiące follisów, celem rozdzielenia ich na potrzeby lokalnych Kościołów w Afryce Północnej. Cecylian miał rozdysponować pieniądze według listy sporządzonej przez Hozjusza, a więc z cesarskiej szczodrobliwości skorzystać mogli jedynie ci, których postawa spotkała się z akceptacją biskupa Kordoby. Konstantyn obiecywał ponadto Cecylianowi dalsze wsparcie finansowe, jeśli tylko ten uzna je za konieczne. Władca nakazał jednocześnie stawiać przed swoimi urzędnikami wszystkich godzących w jedność Kościoła. Wskazywać miał ich zaś, zgodnie z wolą cesarza, właśnie biskup Kartaginy. Na jego wniosek urzędnicy ci mieli ich osądzić i odwieść od błędów, a więc sprowadzić na łono Kościoła, któremu przewodził Cecylian i który był jednocześnie uznawany przez cesarza ${ }^{26}$.

O przychylności władcy do Cecyliana świadczy dobitnie cesarski list skierowany do prokonsula Anulinusa. Konstantyn dał w nim wyraz swemu przekonaniu, że pogardzanie religią, zachowującą cześć dla najświętszych mocy niebieskich, wyrządza sprawom publicznym wielkie szkody. Jeśli natomiast zachowuje się ją zgodnie z prawem, Bóg odwdzięcza się zapewniając pomyślność cesarstwu i wszelkim poczynaniom ludzi. Chcąc zatem zdopingować „sługi Boże” do gorliwego wypełniania swych powinności, przynoszących sprawom publicznym jak największy pożytek, cesarz zwalniał ich od wszelkich powinności państwowych, tzw. munera ${ }^{27}$. Miało to jednak dotyczyć jedynie duchownych $\mathrm{z}$ terenów podległych władzy prokonsula Anulinusa i należących do Kościoła katolickiego, na którego czele stał Cecylian ${ }^{28}$.

Konstantyn zatem, niemal od początku, kiedy zainteresował się sprawą schizmy w Kościele afrykańskim, dążył do położenia jej kresu. Znajdując szybko winnych zaistniałego rozłamu, żądał od nich całkowitej kapitulacji i powrotu do jedności. Znamienne, że domagał się ustępstw tylko od jednej strony konfliktu. Za radą Hozjusza przyznał rację Cecylianowi, biskupowi Kartaginy, winą obarczając jego przeciwników. Jemu też i biskupom znajdują-

25 Por. A. Piganiol, L'empereur Constantin, Paris 1932, 80; W. H. C. Frend, The Donatist Church, s. 163.

${ }^{26}$ Por. Epistula Constantini imperatoris ad Caecilianum, w: Eusebius, HE X 6, SCh 55, 110111

27 Por. J. Gaudemet, Société religieuse et monde lac au Bas Empire, w tegoż: Église et société en Occident au Moyen Age, London 1984, 97.

${ }^{28}$ Por. Epistula Constantini imperatoris ad Anullinum, w: Eusebius, HE X 7, SCh 55, 112-113; J. L. Maier, Le dossier du donatisme, t. 1, 143; zob też Frend, The Donatist Church, s. 146-147; J.Gaudemet, La législation religieuse de Constantin, w: Église et société en Occident au Moyen Age, London 1984, 27-30. 
cym się z nim we wspólnocie przyznał prawo do reprezentowania Kościoła katolickiego w Afryce ${ }^{29}$. Niechęci cesarza do donatystów trudno się dziwić, wszak byli oni rygorystami, a ich bezkompromisowość nie mogła służyć sprawie jedności Kościoła, na której cesarzowi tak zależało ${ }^{30}$. To donatyści dzielili przecież Kościół na dwie wspólnoty: Kościół męczenników i Kościół traditorów.

Dla Konstantyna natomiast taka postawa była niezrozumiała i obca jego mentalności. We wspólnocie Kościoła chciał widzieć wszystkich chrześcijan. Toteż kwestia odpowiedzialności donatystów za rozbicie Kościoła musiała mu wydawać się oczywista, a sam problem ewentualnej winy Feliksa z Abtungi i wysuwane wobec niego oskarżenia o traditio sprawą drugorzędną.

Podjęte przez cesarza działania nie przyniosły oczekiwanych efektów, a sami donatyści ${ }^{31}$ szukali dla siebie szansy odwołując się bezpośrednio do monarchy. Komplementując władcę wskazywali, iż pochodził ze sprawiedliwej rodziny, a jego ojciec nie podjął prześladowań chrześcijan, tak jak czynili to inni cesarze $^{32}$. Prosili, aby Konstantyn wyznaczył w ich sprawie sędziów z Galii, która wolna była od zbrodni (traditio) ${ }^{33}$. Przesłali też na ręce cesarza pismo oprawione w skórę, zatytułowane Libellus ecclesiae catholicae criminum Caeciliani traditus a parte Maiorini, gdzie zebrali swoje oskarżenia pod adresem Cecyliana. Konstantyn, licząc na zażegnanie sporu tą drogą, polecił papieżowi Miltiadesowi i trzem wybranym biskupom galijskim ${ }^{34}$ wysłuchać Cecyliana w obecności 10 jego zwolenników i 10 przeciwników ${ }^{35}$. Wedle słów cesarza, mieli oni starannie zbadać sprawę biskupa Kartaginy i sprawiedliwie ją roz-

${ }^{29}$ Por. Epistula Constantini imperatoris ad Anullinum, w: Eusebius, HE X 7, SCh 55, 112-113; J. L. Maier, Le dossier du donatisme, t. 1, 143; Epistula Constantini imperatoris ad Caecilianum, w: Eusebius, HE X 6, SCh 55, 110-111; zob. też J. Vogt, Upadek Rzymu, thum. A. Łukaszewicz, Warszawa 1993, 104.

${ }^{30}$ Dla T. G. Elliotta (The Christianity, s. 84) jest oczywiste, że Konstanyn „did not share the views of the rigorists".

31 W imieniu wszystkich biskupów z pars Donati list ten sygnowali Lucjan, Dignus, Nazutiusz, Capito oraz Fidencjusz.

${ }^{32}$ Por. Lactantius, De mortibus persecutorum 15, 7, SCh 39, 94.

33 Por. Optatus Milevitanus, Contra Parmenianum I 22, CSEL 26, 25-26. Według E. L. Grasmücka (Coercitio. Staat und Kirche im Donatistenstreit, Bonn 1964, s. 33, przyp. 107) Optat cytuje list donatystów z pamięci, natomiast T. D. Barnes (The Beginnings of Donatism, JTS 26(1975) 20-21) sugeruje, że mamy tu do czynienia z cytatem niekompletnym. Petycją donatystów zajmował się też K. M. Girardet, najpierw w swojej pracy: Kaisergericht und Bischofsgericht, Bonn 1975, 20-26, a potem w artykule: Die Petition der Donatisten an Kaiser Konstantin (Frühjahr 313)historische Voraussetzungen und Folgen, „Chiron” 19(1989) 185-206.

${ }^{34}$ Byli to: Retycjusz z Autun, Maternus z Kolonii i Marinus z Arles.

35 Zgromadzenie to przekształciło się w synod, obradujący w Rzymie pod przewodnictwem papieża Miltiadesa, w którym uczestniczyło ponadto kilkunastu biskupów z Italii; zob. też Frend, The Donatist Church, s. 148; S. Bralewski, Imperatorzy późnego cesarstwa rzymskiego wobec zgromadzeń biskupów, Łódź 1997, 70-71. 
strzygnąć, tak aby położyć kres trwającej schizmie. Konstantyn przypominał im jednocześnie o szacunku, jaki żywił dla prawnie zalegalizowanego Kościoła katolickiego $^{36}$.

Niestety niewiele wiemy na temat przebiegu synodu rzymskiego ${ }^{37}$, gdyż zarówno protokół obrad, jak i list synodu do cesarza zaginęły. Wiadomo jednak, że jego uczestnicy przesłali władcy protokół z obrad, zapewniając, iż wydali wyrok kierując się zasadami sprawiedliwości ${ }^{38}$. Winnych zaistniałej sytuacji upatrywali w oskarżycielach Cecyliana, który z trzydniowej rozprawy wyszedł obronną ręką. $\mathrm{Z}$ jego przeciwników potępiono zaś jedynie Donata za naruszenie dyscypliny kościelnej, powtórne chrzty i spowodowanie schizmy. Dla pozostałych biskupów z pars Donati zgromadzeni w Rzymie stworzyli dogodne warunki powrotu na łono Kościoła. Mogli oni zachować swe godności kościelne. W miastach zaś, gdzie mieli swe siedziby zarówno biskupi należący do zwolenników Cecyliana, jak i ci należący do obozu Donata, zdecydowano pozostawić na czele Kościoła starszych w biskupstwie, a więc wcześniej nań wyświęconych, przewidując dla młodszych możliwość przeniesienia na inne biskupstwa $^{39}$. Według T.D.Barnesa wydany wyrok był próbą wprowadzenia rozłamu w obozie schizmatyków, oraz zmierzał do izolacji Donata i pozbawienia go zwolenników ${ }^{40}$.

Po zbadaniu sprawy Konstantyn przyznał uczestnikom synodu rację, spodziewając się zakończenia w ten sposób „wszystkich podziałów i sporów” ${ }^{41}$. Jak się wydaje, nie było to tylko retoryczne stwierdzenie. Oczekiwania cesarza związane z synodem rzymskim mogą dowodzić, że zebrani na nim biskupi skupili swoją uwagę przede wszystkim na ustaleniu generalnej zasady dotyczącej ważności sakramentów chrztu i kapłaństwa, nawet w sytuacji, gdyby zostały udzielone przez osoby niegodne. Dopiero ewentualne jej przyjęcie odbierałoby wszelki sens ( $z$ punktu widzenia Kościoła jako wspólnoty) bardzo trudnym dociekaniom co do winy traditio poszczególnych duchownych, w tym Feliksa

${ }^{36}$ Por. Epistula Constantini imperatoris ad Miltiadem, w: Eusebius, HE X 5, SCh 55, 108-109; zob. też J. L. Maier, Le dossier du donatisme, t. 1: Des origines à la mort de Constance II (303-361), Berlin 1987, 150; E.Griffe, La Gaule chrétienne à l'époque romaine, t. 1: Dès origines chrétiennes à la fin du IVe siècle, Paris 1964, 186-190.

${ }^{37}$ Na temat synodu w Rzymie zob. E.Caspar, Die römische Synode von 313, ZKG 46(1928), 333-346; K. M. Girardet, Kaisergericht und Bischofsgericht, Bonn 1975, 27-35; Ch. Pietri, L'échec de l'unité „impériale” en Afrique, s. 234-235.

${ }^{38}$ Por. Epistula Constantini imperatoris ad Aelafium, CSEL 26, 205.

${ }^{39}$ Por. Augustinus, Breviculus Collationis cum Donatistis III 12, CSEL 53, 72-73; Augustinus, Epistula, 43, 16, CSEL 34, 97-98; C. J. Hefele, Histoire des conciles d'après les documents originaux, trad. H. Leclercq, t. 1, Paris 1907, 272-273.

${ }^{40}$ Por. T. D. Barnes, Constantine and Eusebius, London 1981, 57.

${ }^{41}$ Epistula Constantini ad Aelafium, CSEL 26, 205: „....speraueram quod omnibus omnino seditionibus et contentionibus, quae ab his hominibus uidebantur subito commotae, finis debitus fuisset impositus". 
z Abtungi, i tym samym dawało nadzieje na zakończenie sporów. Zarzuty wysuwane przez donatystów pod adresem synodu w Rzymie, dotyczące niewielkiej liczby uczestników, pobieżnego tylko zbadania sprawy, czy też wydania wyroku w pośpiechu ${ }^{42}$ i to stronniczego ${ }^{43}$, wydają się potwierdzać powyższe przypuszczenia. Zasadę ogólną można było ustalić szybko, bez szczegółowego rozpatrywania oskarżeń donatystów, ale czy zgromadzenie tak skromne liczebnie miało prawo ją formułować w imieniu całego Kościoła? Ten argument Konstantyn musiał wziąć pod uwagę i dlatego zdecydował się sprawę schizmy powierzyć zgromadzeniu o wiele liczniejszemu. Spodziewał się ponadto, ze udział w obradach szerokiej reprezentacji biskupów pomoże ostatecznie konflikt zakończyć.

Czy zatem władca, powierzając zgromadzonym w Rzymie rozpatrzenie zarzutów wysuwanych przeciwko Cecylianowi, liczył na bezstronne zbadanie sprawy, czy też może raczej na to, że donatyści podporządkują się autorytetowi owych „sędziów z Galii”, o których prosili. Dla Konstantyna przecież wina schizmatyków nie ulegała wątpliwości od samego początku, a on sam Kościół katolicki w Afryce utożsamiał z Cecylianem i jego zwolennikami. Zwraca uwagę, że wedle słów cesarskich to Cecylian miał być wysłuchany w Rzy$\mathrm{mie}^{44}$. Można więc podejrzewać, że wolą Konstantyna było, aby zebrani tam duchowni umożliwili biskupowi Kartaginy oczyszczenie się z ciążących na nim zarzutów.

3. Synod w Arles. Ponieważ wydany przez synod w Rzymie wyrok kwestionowali donatyści ${ }^{45}$, władca powierzył ponowne zbadanie sprawy kolejnemu zgromadzeniu biskupów, zwołanemu tym razem do Arles (Arelate) w 314 roku $^{46}$, zapewniając mu jednak wyższą rangę, dzięki znacznie rozszerzonej liczbie uczestników ${ }^{47}$.

${ }^{42}$ Por. Epistula Constantini imperatoris ad Chrestum, w: Eusebius, HE X 5, SCh 55, 109-110.

${ }^{43}$ Według cesarza donatyści uskarżali się, że biskupi w Rzymie wydali wyrok, który im, biskupom, odpowiadał, por. Epistula Constantini imperatoris ad Aelafium, CSEL 26, 205

${ }^{44}$ Por. Epistula Constantini imperatoris ad Miltiadem, w: Eusebius, HE X 5, SCh 55, 108:

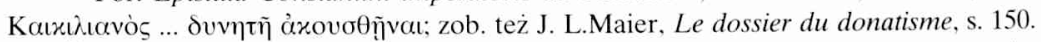

${ }^{45}$ Donatyści kwestionowali bezstronność Miltiadesa, gdyż oskarżali o apostazję papieża Marcellina, od którego otrzymał święcenia. O „traditio” podejrzewany był też sam Miltiades; zob. W. H. C.Frend, The Donatist Church, s. 22 i 149. Według T. G. Elliotta (The Christianity, s. 87) donatyści kwestionowali wyrok synodu rzymskiego, przede wszystkim dlatego, że ,it had not been rendered by an exclusively Gallic council".

${ }^{46}$ Por. K. M. Girardet, Konstantin der Grosse und das Reichskonzil von Arles (314). Historisches Problem und methodologische Aspekte, w: Oecumenica et Patristica. Festschrift W. Schneemelcher, Stuttgart 1989, 151-174; Ch. Pietri, L'échec de l'unité „impériale” en Afrique, s. 235-236.

${ }^{47} \mathrm{Na}$ temat składu synodu w Arles por.: S. Bralewski, Imperatorzy późnego cesarstwa rzymskiego wobec zgromadzeń biskupów, Łódź 1997, 71-74. 
Poinformował listownie o podjętej decyzji Aelafiusza, wikariusza Afryki, zlecając mu jednocześnie określone zadania związane $z$ organizacją synodu ${ }^{48}$. Cesarz wskazywał przy tym na mające miejsce w kościele afrykańskim liczne przypadki „bezrozumnego szaleństwa”, wiodącego do wzajemnych bezzasadnych oskarżeń, godzących w religię katolicką. W tym kontekście nawiązywał do osoby Cecyliana i wysuwanych przeciw niemu oskarżeń, widząc w nim nadal prawowitego biskupa Kartaginy. Wspominał następnie o synodzie w Rzymie, który zwołał, aby położyć temu kres. Na koniec listu cesarz dzielił się z Aelafiuszem refleksją, że nie może pozwolić sobie na lekceważenie tego rodzaju sporów, gdyż mogłyby one obrócić gniew Boży nie tylko na rodzaj ludzki, ale także na niego samego, któremu wola Boża powierzyła kierowanie wszystkimi sprawami ziemskimi ${ }^{49}$.

Imienne zaproszenia na obrady synodu w Arles Konstantyn skierował do pewnej liczby biskupów, trudnej obecnie do ustalenia, gdyż ze wszystkich listów, jakie wysłał w tej sprawie, zachował się tylko jeden. Zamieścił go Euzebiusz z Cezarei w swojej Historii Kościoła ${ }^{50}$. W piśmie tym, adresowanym do Chrestusa, biskupa Syrakuz, władca wyraża najpierw swe ubolewanie, że waśń dzieląca Kościół afrykański mimo podejmowanych przez niego wysiłków nie znalazła swego zakończenia. Według cesarza, spór ten został wnikliwie zbadany przez biskupów obradujących pod przewodnictwem papieża, jednak wydany przez nich sprawiedliwy wyrok nie został uszanowany. Winą za to obarczał władca donatystów, choć nie zostali imiennie wskazani. Gorzkie słowa kierował Konstantyn pod adresem tych, którzy zapomnieli o swym zbawieniu oraz o czci, jaką byli winni świętej religii, a w dodatku nie potrafili wznieść się ponad osobiste urazy i nie chcieli zaakceptować wydanego już wyroku. Wyraża w końcu cesarz nadzieję, że nowe zgromadzenie położy kres „temu, co powinno się zakończyć po wyroku już wydanym" ${ }^{51}$. Nie można więc żywić jakichkolwiek wątpliwości co do tego, że Konstantyn miał jasno sprecyzowane poglądy na temat schizmy ${ }^{52}$, i że całkowitą winę składał na barki donatystów. Władca liczył, iż tym razem podporządkują się oni woli wyrażonej jednomyślnie przez zgromadzonych biskupów, tym bardziej, że ci zobowiązani zostali do wysłuchania wszystkiego, co do powiedzenia będą miały obydwie skłócone strony ${ }^{53}$.

Biskupi zgromadzeni w Arles, zgodnie z oczekiwaniami władcy, odmówili racji donatystom. Skoncentrowali się zaś na ustaleniu wspomnianych już

48 Epistula Constantini imperatoris ad Aelafium, CSEL 26, 204-206.

49 Epistula Constantini imperatoris ad Aelafium, CSEL 26, 206.

${ }^{50}$ Epistula Constantini imperatoris ad Chrestum, Eusebius, HE X 5, SCh 55, 109-110.

51 Epistula Constantini imperatoris ad Chrestum, w: Eusebius, HE X 5, SCh 55, 109-110.

${ }^{52}$ E. Wipszycka (Kościót w świecie późnego antyku, Warszawa 1994, 15) jest również przekonana, że w sprawie schizmy w Kościele kartagińskim ,,cesarz od początku wiedział jak należy postępować”.

${ }^{53}$ Por. Epistula Constantini imperatoris ad Chrestum, w: Eusebius, HE X 5, SCh 55, 109. 
zasad ogólnych. W kanonie 8 postanowili o ważności sakramentu chrztu, nawet jeśli został przyjęty z rąk heretyków. Niektórzy historycy są zdania, że biskupi czyniąc tu aluzje do donatystów, starali się zasugerować generalną zasadę ważności wszystkich sakramentów, nawet gdyby udzielała ich osoba niegodna ${ }^{54}$. W kanonie 13 natomiast biskupi uznali ważność święceń tych wszystkich, którzy otrzymali je od osób winnych traditio. Wyraźnie więc nawiązywano do sprawy Cecyliana i oskarżeń kierowanych pod adresem Feliksa z Abtungi przez donatystów ${ }^{55}$. Uchwalenie wspomnianych kanonów musiało odpowiadać cesarzowi, jeśli wręcz nie było przez niego inicjowane, gdyż służyło jedności Kościoła i mogło położyć kres wszystkim sporom, wybuchającym wokół licznych przypadków zdrady jednostek, a w dodatku w przyszłości mogło zapobiec rozłamom wśród chrześcijan. Kanon 13 dowodził ponadto, że dla uczestników synodu w Arles sprawa ewentualnej winy Feliksa wydawała się drugorzędną i taki sposób jej postrzegania podzielał również sam władca.

Donatyści kolejny już raz nie zamierzali jednak zaakceptować niekorzystnego dla nich wyroku prosząc, aby sam cesarz został sędzią w ich sporze. Władca informował o tym biskupów w specjalnym liście skierowanym do uczestników synodu w Arles. Nazywał w nim donatystów ludźmi zwiedzionymi przez złośliwość diabła, sługami szatana, którzy odwracając się od prawdy, połączyli się z poganami. Z oburzeniem konstatował, że nie chcąc podporządkować się Opatrzności, proszą o cesarski wyrok. „Domagają się mojego sądu, pisał cesarz, ode mnie, który sam oczekuję sądu Chrystusa!”. W opinii władcy, wyrok wydany przez biskupów musi być uważany za wyrok Boga samego, „,jakby sam Pan sądził ze swego tronu”, i „,nie wolno myśleć, ani sądzić inaczej, niż nauczał Chrystus". Konstantyn zarzucał donatystom, iz pilnują spraw doczesnych, kosztem wiecznych. Toteż zapowiadał wysłanie swoich ludzi aby sprowadzili na cesarski dwór owych ,wstrętnych zwodzicieli religijnych”, co miało być dla nich gorsze niż śmierć. Poszukiwać ich miano także w Afryce, zanim sprowokują gniew Opatrzności Bożej ${ }^{56}$. Wygnanie liderów pars Donati trwało jednak tylko kilka miesięcy ${ }^{57}$, po czym cesarz zezwolił im powrócić do swych siedzib ${ }^{58}$.

${ }^{54}$ Por. Hefele-Leclercq, t. 1, 285-287.

55 Por. tamze, t. 1, 289-291.

56 Por. Epistula Constantini ad episcopos catholicos, CSEL 26, 208-210.

57 Cesarz zezwolił im na powrót wiosną 315 roku, o czym świadczy list wysłany przez Petroniusza Annianusa i Juliana do Domicjusza Celsusa, wikariusza Afryki, datowany 28 kwietnia najprawdopodobniej 315 roku. O kontrowersjach wokół tej daty zob. J. L.Maier, Le dossier du donatisme, t. 1, s. 187-188, przyp. 2.

58 Por. Epistula Petronii, CSEL 26, 212. Wrócili wtedy biskupi: Lucjanus, Capito, Fidencjusz i Nazucjusz oraz kapłan Mammariusz. To ci biskupi w roku 313 kierowali do cesarza prośbę o sędziów z Galii. 


\section{4. Śledztwo w sprawie Feliksa z Abtungi. Na przełomie lat 314/315 urzęd-} nicy cesarscy pod przewodnictwem Aelianusa, prokonsula Afryki, przeprowadzili na polecenie Konstantyna śledztwo w sprawie Feliksa z Abtungi, które oczyściło go z zarzutów wysuwanych pod jego adresem przez donatystów ${ }^{59}$. Trudno jednak oprzeć się wrażeniu, że jego przebieg był sterowany przez cesarskich funkcjonariuszy. W trakcie śledztwa bowiem Alfiusz Cecylian, urzędnik municypalny z Abtungi, biorący za panowania Dioklecjana bezpośredni udział w realizacji edyktu o prześladowaniach chrześcijan, wycofał swoje wcześniejsze oświadczenie, obciążające Feliksa winą o traditio. Dochodzenie wykazało ponadto, że jego poprzednią relację sfałszował niejaki Ingencjusz, który na torturach przyznał się do winy ${ }^{60}$. Nie ulega wątpliwości, że wynik śledztwa bardzo odpowiadał cesarzowi, gdyż potwierdzał słuszność jego dotychczasowej polityki wobec donatystów i zgodny był z wyrokami, jakie w ich sprawie uchwalali sami biskupi. Potwierdzenie winy Feliksa stawiałoby natomiast władcę w bardzo kłopotliwej sytuacji wprowadzając, z cesarskiego punktu widzenia, zamęt w Kościele i utrudniając przywrócenie jedności, która miała się dokonać poprzez „kapitulację” donatystów, jak wyobrażał to sobie cesarz. Wszak Konstantyn wyrażał nadzieję, że dzięki uwolnieniu Feliksa od zarzutów kłótnie mające miejsce w Kościele afrykańskim wreszcie wygasną ${ }^{61}$. Sam problem rzeczywistej winy Feliksa był natomiast dla cesarza naprawdę nieistotny. Tak czy owak władca nie mógł zaakceptować nieprzejednanej postawy donatystów, bo godząc się na nią, musiałby zrezygnować z marzeń o jedności Kościoła.

W liście do Probianusa, prokonsula Afryki, cesarz powoływał się na wyniki wspomnianego śledztwa. Przypominał, że Aelianus, poprzednik prokonsula zbadał „sprawę, albo przedmiot nienawiści” ${ }^{2}$ do Cecyliana, którego cesarz nadal nazywał biskupem Kościoła katolickiego. Konstantyn polecił następnie sprowadzić na dwór pod strażą wspomnianego Ingencjusza, aby ci, którzy nieustannie odwołują się do władcy w sprawie schizmy, mogli się sami przekonać o niedorzeczności oskarżeń wysuwanych przeciwko Cecylianowi ${ }^{63}$.

5. Cesarski sąd w Mediolanie. Kilka tygodni później Konstantyn skierował list do schizmatyckich biskupów. Informował w nim, że jakiś czas temu zezwolił

${ }^{59}$ Por. Acta purgationis Felicis episcopi Autumnitani, CSEL 26, 204: „Felicem autem religiosum episcopum liberum esse ab exustione instrumentorum deificorum manifestum est, cum nemo in eum aliquid probare potuerit quod religiosissimas scripturas prodiderit uel exusserit".

${ }^{60}$ Por. tamże, CSEL 26, 197-204.

${ }^{61}$ Por. Epistula Constantini et Licini ad Probianum proconsulem Africae, CSEL 34/2, 411: ,Ita enim fiet ut, omissis sicuti oportet eius modi contentionibus, populus sine dissensione aliqua religioni propriae cum debita ueneratione deseruiat".

62 Tamże, CSEL 34/2, 410: ,negotium vel invidiam”, jak to określił władca.

${ }^{63}$ Por. tamże, CSEL 34/2, 410-411. 
im na powrót do Afryki, o co sami zresztą zabiegali. Cesarz spodziewał się, że przedstawią tam wszystkie swoje zarzuty wobec Cecyliana przed specjalnymi wysłannikami władcy, określanymi w liście mianem cesarskich przyjaciół. Monarcha liczył, że w ten sposób będzie można sprawie biskupa Kartaginy położyć w końcu kres. Musiał jednak zmienić plany, o czym donosił donatystom, gdyż niektórzy $\mathrm{z}$ nich wszczynali zamieszki i trwając $\mathrm{w}$ swoim uporze, nie mieli żadnego poszanowania dla sprawiedliwych sądów, ani dla oczywistej praw$\mathrm{dy}^{64}$, gdyby nie to, sprawa znalazłaby już swój finał, a tak mimo starań cesarza uszczerbku doznaje Majestat Boski ${ }^{65}$. Toteż wydawało się władcy słuszne wezwać do siebie Cecyliana, aby w jego obecności dać szansę donatystom wykazania prawdziwości wysuwanych wobec niego zarzutów, przy czym cesarz zapowiadał, że jeśli tylko wykażą słuszność choćby jednego z nich, to mu wystarczy, aby uznać także pozostałe ${ }^{66}$. Według słów Konstantyna, domagał się on już wcześniej przybycia Cecyliana na dwór cesarski. Niemniej władca wyrażał nadzieję, że tym razem biskup Kartaginy, ponaglany przez oficjalne pismo, będzie tam wkrótce obecny. Późniejsze świadectwo Augustyna z Hippony dowodzi jednak, że duchowny nie stawił się wówczas przed cesarzem ${ }^{67}$.

W opinii W. H. C. Frenda, po oczyszczeniu Feliksa z Abtungi z ciążących na nim oskarżeń o wydanie Świętych Ksiąg, Konstantyn był bliski rozstrzygnięcia sporu na korzyść Cecyliana. Kiedy jednak biskup Kartaginy nie stawił się na wezwanie monarchy, ten zaczął się skłaniać ku donatystom, obiecując przyznanie im racji, jeśli tylko dowiodą jednego choćby zarzutu wysuwanego wobec Cecyliana $^{68}$.

List do biskupów schizmatyckich, na który powołuje się Frend, nie daje jednak podstaw do takich wniosków, wszak cesarz, jak starałem się to wykazać, ostro ganił w nim donatystów. Natomiast przyrzeczenie, jakie im złożył, dowodzi raczej jego niewiary w możliwość przekonania go do racji schizmatyków. Cesarz, jak widać, był do nich zrażony tak dalece, iż nie dopuszczał nawet myśli, aby mogli go przekonać choćby w jednym punkcie do swoich poglądów. Stąd zapewne wypływała nonszalancja, z jaką składał obietnicę, która nie miała szans na realizację. Wyraźnie Konstantyn starał się wykazać wobec donatystów swą dobrą wolę i bezstronność, aby przekonać ich w ten sposób do podporządkowania się zapadłym już wyrokom. Do planowanej wówczas konfrontacji nie doszło, gdyż, o czym była już mowa, Cecylian nie przybył, a donatyści powrócili

${ }^{64}$ Cesarz wskazywał na nieposzanowanie przez nich ,,rectum iudicium et integrae veritatis rationem" (Epistula Constantini imperatoris ad episcopos donatistas, 1-28, CSEL 26, 210).

65 Por tamże.

${ }^{66}$ Por. tamze CSEL 26, 211: „Polliceor autem vobis quod, si praesente ipso de uno tantum crimine uel facinore eius per uosmet ipsos aliquid probaueritis, id apud me sit ac si uniuersa quae ei intenditis probata esse uideantur".

${ }^{67}$ Por. Augustinus, Epistula 43, 7, 20, CSEL 34/2, 102.

${ }^{68}$ Por. Frend, The Donatist Church, s.155-156. 
samowolnie do Afryki. Ośmielili się na to, zdaniem Frenda, uskrzydleni okazaną im łaską, jednak ich postępek spotkał się z surową reakcją monarchy ${ }^{69}$. Wbrew Frendowi dowodzi to raczej, że Konstantyn łaskawy im nie był.

W relacji Optata z Milewe ${ }^{70}$ w czasie, gdy władca zajęty był walką z Frankami, donatystom udało się pozyskać na dworze cesarskim kilku urzędników. Jednym $\mathrm{z}$ nich był Filumenos ${ }^{71}$, który miał zaproponować monarsze kompromisowe rozwiązanie prowadzonego w Afryce sporu. Pod wpływem jego sugestii cesarz nie zezwolił Donatowi na powrót do Kartaginy, zatrzymując jednocześnie dla dobra pokoju Cecyliana w Brescji (Brixiae) ${ }^{72}$ w Italii. Zimą 315/316 roku $^{73}$ wysłano do Afryki ze specjalną misją dwóch biskupów, Olimpiusza i Eunomiusza, polecając im wyszukać nowego kandydata na biskupa Kartaginy, na którego zgodziłyby się obie strony konfliktu. Wobec wrogości donatystów cesarscy wysłannicy nie osiągnęli celu i po czterdziestu dniach pobytu w Kartaginie wrócili z niczym ${ }^{74}$. Według Augustyna donatyści żądali od Konstantyna potępienia Cecyliana i internowania go w Brescji ${ }^{75}$.

Dla cesarza najważniejsze było przywrócenie jedności Kościoła, i choć był ustosunkowany wobec donatystów bardzo krytycznie, gotów był jak widać do ustępstw. Trudno natomiast powiedzieć, czy władca wierzył w możliwość osiągnięcia jakiegokolwiek kompromisu ze schizmatykami, tak bardzo przesiąkniętymi rygoryzmem. W każdym razie propozycję wysłania misji podjął, być może ze względu na cień szansy na sukces, czy też chcąc po prostu zrobić wszystko, co w jego mocy, aby zaprowadzić w Kościele afrykańskim pokój ${ }^{76}$. Usuwając ze sceny wydarzeń obydwu przywódców zwalczających się obozów, Konstantyn pragnął także z pewnością wykazać dobrą wolę wobec donatystów i przekonać ich do swej bezstronności.

Pomysł przeprowadzenia nowego wyboru biskupa Kartaginy w związku z narastaniem konfliktu trzeba traktować za całkowicie naturalny, jeśli zwa-

${ }^{69}$ Por. tamże, s. 156.

${ }^{70}$ Por. Contra Parmenianum I 26, CSEL 26, 28-29.

${ }^{71}$ Filumenos, magister officiorum, w czasie gdy obradował Sobór w Nicei, należał do bliskich współpracowników cesarza Konstantyna Wielkiego; to on na polecenie władcy miał zbierać od biskupów podpisy pod nicejskim credo, zob. Philostorgius, HE I 7, oraz 7 a, GCS 21, 8-9.

72 Donatyści utrzymywali, że Cecylian znalazł się w Brescji na wygnaniu, gdyż został potępiony przez Konstantyna; por. Augustinus, Contra Cresconium III 69, 80, „Bibliothèque augustinienne" 31, 434; zob. też A. C. de Veer, Le séjour de Caecilianus à Brescia, tamże, s. 822-824.

73 Tak datuje ją W.H.C.Frend (The Donatist Church, s. 156), według P.Monceaux (Histoire littéraire de l'Afrique chrétienne, t. 5: Saint Optat et les premiers écrivains donatistes, Paris 1920, 490) miała ona miejsce latem 316 roku), a zdaniem E. L. Grasmücka (Coercitio. Staat und Kirche im Donatistenstreit, Bonn 1964, 82) wiosną albo latem 316 roku.

74 Por. Optatus, Contra Parmenianum I 26, CSEL 26, $28-29$.

${ }^{75}$ Por. Augustinus, Breviculus collationis III 20,38; zob. też E. Lamirande, La prétendue condamnation de Caecilianus par Constantin, ,,Bibliothèque augustiniennne” 32, Paris 1965, s. 734.

${ }^{76}$ Władca kierował się przecież poczuciem obowiązku wobec Boga. 
żyć, że schizma zaczęła się od kontrowersji wokół tej elekcji. Decyzja cesarska w rzeczonej sprawie nie musi więc dowodzić, wbrew przekazowi Optata, pozyskania przez donatystów wpływowych osób z otoczenia władcy. Wydaje się również, że można w niej widzieć uzasadnienie dla wcześniejszej nieobecności Cecyliana na cesarskim dworze ${ }^{77}$, wszak decyzji tej Konstantyn nie podjął nagle. Musiał już nosić się z nią od pewnego czasu i jest wielce prawdopodobne, że Cecylian był tego świadomy. Trudno zatem dziwić się, iż nie spieszno mu było na wezwanie monarchy, skoro musiał liczyć się z utratą biskupiego tronu.

Wkrótce po zakończeniu misji Olimpiusza i Eunomiusza, Donat zbiegł samowolnie do Afryki, gdzie powrócił też Cecylian. Niepokojące wieści o fiasku podjętych działań i niepomyślnym rozwoju wydarzeń dotarły do cesarza w Trewirze na początku roku 316. Wtedy to Konstantyn postanowił sam udać się do Afryki, aby w końcu położyć kres schizmie ${ }^{78}$. Informował o tym w liście wystosowanym do Domicjusza Celsusa, tamtejszego wikariusza ${ }^{79}$. Wspomina w nim o nowych rozruchach w Afryce, wywołanych przez ludzi owładniętych szaleństwem, którzy popadając w straszliwy błąd oddalili się od prawdy Bożej ${ }^{80}$. Do niepokojów doszło, kiedy wikariusz przystąpił do wykonywania cesarskich rozkazów nakazujących ukaranie ich niesubordynacji. Tekst więc wyraźnie nawiązuje do donatystów, wszak to oni nie chcieli podporządkować się wydanym przeciwko nim wyrokom. Wobec ich „,bezbożnych planów" cesarz postanowił sam zbadać sprawę na miejscu, przy czym zapowiadał, że dochodzenie zostanie przeprowadzone $\mathrm{z}$ wielką starannością. Polecił Celsusowi poinformować o tym zarówno Cecyliana jak i jego przeciwników. Wikariusz Afryki miał do czasu przeprowadzenia cesarskiego sądu zaniechać podejmowania jakichkolwiek działań godzących w donatystów ${ }^{81}$. Rozsądzając skłóconych cesarz myślał im pokazać, jakim szacunkiem należy otaczać Majestat Boski, i w jaki sposób należy oddawać Mu cześć. Groził, że ujawni skryte zamysły i „powali” tych wszystkich, którzy wszczynając spory uwłaczają samemu Bogu. Czynił jednocześnie wyraźne aluzje do postępowania donatystów, potępiając ich skłonność do szukania chwały męczeństwa, co kłóciło się w opinii władcy z wyznawaną przez nich religią. Konstantyn zapowiadał następnie, że ci,

77 J. L. Maier (Le dossier du donatisme, t. 1, 193, przyp. 9) podkreśla, iż nie wiadomo dlaczego Cecylian pozostawał w Afryce, mimo wezwań cesarza.

${ }^{78}$ Zdaniem W.H.C.Frenda (The Donatist Church, s. 157) decyzja cesarska wynikała z braku zaufania do obydwu skłóconych stron.

${ }^{79}$ Por. Epistula Constantini imperatoris ad Celsum, CSEL 26, 211-212.

${ }^{80} \mathrm{~W}$ liście do Celsusa cesarz wymienia jednego $\mathrm{z}$ winnych, niejakiego Menaliusza, por. Epistula Constantini imperatoris ad Celsum, CSEL 26, 211.

${ }^{81}$ Dla W. H. C.Frenda (The Donatist Church, s. 157) jest to dowód, że cesarz wahał się co do tego, komu przyznać rację w sporze. Świadczy o tym równiez, według niego, zgoda władcy na powrót pozostałych donatystów do Afryki. Jeśli jednak Konstantyn zdecydował się na ponowne rozpatrzenie sprawy, nie mógł postąpić inaczej, nie chcąc narazić się na zarzut stronniczości. 
których uzna za sprzeciwiających się woli Bożej i samej religii, zostaną przykładnie ukarani, bez względu na ich szaleństwo i zuchwały upór ${ }^{82}$.

Zdaniem W. H. C. Frenda, w liście tym, po raz pierwszy i ostatni, Konstantyn jednakowo traktował obydwie strony sporu. Zapowiadał bowiem, że zarówno Cecylianowi, jak i jego przeciwnikom wskaże poprzez swój werdykt, jaką cześć należy oddawać Najwyższemu Bogu. Świadczyć miałby za tym też fakt, że monarcha nie wspominał w rzeczonym piśmie ani o synodzie papieża Miltiadesa, ani o synodzie w Arles, ani też o uniewinnieniu Feliksa z Abtun$\mathrm{gi}^{83}$. W moim przekonaniu, cesarz nie zachowywał jednak bezstronności, mimo iż obiecywał przeprowadzenie gruntownego śledztwa i dokładne zbadanie sprawy. W liście do wikariusza Celsusa władca nie ukrywał bowiem niechęci do donatystów. To pod ich adresem konsekwentnie kierował oskarżenia o szaleństwo i upór, to ich obciążał odpowiedzialnością za bieg wypadków w Kościele afrykańskim ${ }^{84}$. Nie powoływał się natomiast na wcześniej wydane już w tej sprawie wyroki, gdyż to on tym razem swoim autorytetem miał zastąpić trybunały kościelne, którym sam wcześniej nadawał rangę sądu Chrystusa. Zdecydował się rozsądzić skłóconych osobiście, bo nie widział już innej możliwości przywrócenia jedności Kościoła. O determinacji cesarza najlepiej świadczy refleksja zamieszczona na końcu listu: cesarz pytał, co jeszcze może zrobić, aby rugując wszelkie błędy i zuchwałości doprowadzić do powszechnej zgody, przywrócić prawdziwą pobożność i kult należny Wszechmocnemu Bogu ${ }^{85}$.

Ostatecznie Konstantyn rozpatrzył konflikt osobiście w roku 316, jednak nie w Afryce, a w Mediolanie ${ }^{86}$. Kolejny też raz stanął po stronie Cecyliana, a przeciw donatystom. Władca ogłosił całkowitą niewinność biskupa Kartaginy, uznając, że dobrze służy swej religii i że nie można mu zarzucić żadnego występku, a dotychczasowe oskarżenia były wymysłem jego adwersarzy ${ }^{87}$.

${ }^{82}$ Por. Epistula Constantini imperatoris ad Celsum, CSEL 26, 211-212.

${ }^{83}$ Por. Frend, The Donatist Church, s. 157-158.

${ }^{84}$ Konsekwentnie oskarżał ich wcześniej o .,insania” i „obstinatio”, zob. Epistula Constantini imperatoris ad Caecilianum 2, w: Eusebius, HE X 6. SCh 55, 110-111; Epistula Constantini imperatoris ad episcopos catholicos, CSEL 26, 208-210; Epistula Constantini imperatoris ad episcopos donatistas, CSEL 26, 10-211; Epistula Constantini imperatoris ad Celsum, CSEL 26, 211-212.

85 Por. Epistula Constantini ad Celsum, CSEL 26, 212: ,Quid potius agi a me pro instituto meo ipsiusque principis munere oporteat quam ut discussis erroribus omnibusque temeritatibus amputatis ueram religionem uniuersos concordemque simplicitatem atque meritam omnipotenti deo culturam praesentare perficiam?".

${ }^{86}$ Optatus, Contra Parmenianum I 26, CSEL 26, 28.

${ }^{87}$ Por. Epistula Consatntini imperatoris ad Eumalium, w: Augustinus, Contra Cresconium grammaticum et donatistam CSEL 52, 487; J. L. Maier, Le dossier du donatisme, t. 1, 198. Zdaniem ks. T. Kołosowskiego (Polityka religijna Konstantyna Wielkiego w świetle schizmy donacjańskiej, „Saeculum Christianum” 1:1995, 32) donatyści zostali skazani przez Konstantyna „nie jako schizmatycy, ale jako zniesławiający Cecyliana”. 
6. Represje. Ponieważ i tym razem, mimo iż chodziło o wyrok samego cesarza, donatyści nie chcieli podporządkować się mu, zniecierpliwiony Konstantyn podjął próbę przywrócenia jedności chrześcijan mocą dekretu wydanego wiosną 317 roku. Zapowiadał w nim podjęcie surowych sankcji przeciwko donatystom, włącznie $z$ odebraniem im zajmowanych przez nich kościołów, a w szczególnych przypadkach nawet wygnaniem ${ }^{88}$. Ponieważ użyte przez cesarza wojsko i zastosowane represje dla wymuszenia egzekucji wydanych wyroków nie tylko, że nie przywróciły upragnionego pokoju, ale zaostrzyły konflikt $^{89}$, cesarz wiosną ${ }^{90} 321$ roku zrezygnował z rozwiązań siłowych ${ }^{91}$ i odwołał donatystów z wygnania ${ }^{92}$, aby w ten sposób przywrócić spokój w prowincji. Szykował się wtedy do wojny z Licyniuszem i z pewnością zdrowy rozsądek nakazywał, aby zaogniony konflikt jakoś załagodzić. Być może więc rozwój wypadków politycznych przyśpieszył odwrót Konstantyna od polityki represji wobec donatystów. Faktem jest jednak, że kiedy cesarz został jedynowładcą imperium, nie powrócił już do brutalnych metod rozprawy z owymi schizmatykami, chociaż miał po temu możliwości i nigdy wcześniej jego pozycja w państwie nie była tak silna i ustabilizowana, jak wówczas. Uznać więc musiał nieskuteczność rozwiązań siłowych, toteż nie zamierzał powielać błędów już popełnionych $^{93}$.

Pozostawienie donatystów w spokoju przez władze państwowe spotkało się z nienajlepszym przyjęciem ze strony katolików, toteż cesarz skierował list do afrykańskich biskupów i ludu Kościoła powszechnego, usprawiedliwiając swą decyzję $e^{94}$. Konstantyn przypominał w nim o swoich wysiłkach podejmowanych dla zachowania pokoju i zgody, storpedowanych jednak przez gwałty nielicznej grupy. Cesarz podkreślał, że podjęte przez niego działania nie odniosły żadnego skutku, a wręcz przeciwnie, umocniły jeszcze schizmatyków, „dostarczając ich występkowi usprawiedliwienia”. Konstantyn świadomy, że represje przy-

${ }^{88}$ Edykt ten do naszych czasów nie zachował się, jest jednak wspomniany w rozporządzeniu Gracjana-Codex Theodosianus 16, 6, 2; zob. też J. L. Maier, Le dossier du donatisme, t. 1, 198-200.

${ }^{89}$ Represje zostały przeprowadzone przez urzędników cesarskich z wykorzystaniem wojska, a ich brutalny charakter i opór stawiany przez donatystów doprowadziły do przelewu krwi; por. Passio Donati Abiocalensis, w: J. L.Maier, Le dossier du donatisme, t. 1, 201-211; zob. też P. Monceaux, Le Donatisme, s. 29. Na wzmocnienie oporu donatystów na skutek represji zwracała też uwagę L. W. Barnard (Church-State Relations, A.D.313-337, „Journal of Church and State” $24: 1982$, s. 344).

${ }^{90}$ Być może miało to miejsce 5 maja, tak bowiem wedhug św. Augustyna (Ad Donatistas post collationem 33, 56, CSEL 53, 158-159) datowany był list, jaki cesarz wysłał w tej sprawie do Verinusa, ówczesnego wikariusza Afryki.

${ }_{91}$ Por. Maier, Le dossier du donatisme, t. 1, 239-242.

92 Por. Augustinus, Ad Donatistas post collationem 31, 54, „Biblithèque augustinienne” 32 , s. 378 .

93 Por. Drake, Constantine and the Bishops, s. 221.

${ }^{94}$ Por. Epistula Constantini imperatoris ad universos episcopos per Africam et plebem catholicam, CSEL 26, 212-213. 
sparzają tylko donatystom męczenników, z czego ich Kościół czerpał powód do chwały, postanowił całkowicie zdać się w sprawie schizmy na Boga. Toteż czekając na Bożą interwencję, zapowiadał zmianę swej dotychczasowej polityki. Namawiał katolików do cierpliwego znoszenia wybryków donatystów i nie odpłacania im za krzywdy, których się dopuszczają, gdyż jego zdaniem trzeba pozostawić pomstę samemu Bogu. Należy troszczyć się o zachowanie wiary, a wszystkie cierpienia z tej racji poniesione skutkiem szaleństwa ludzi z pars Donati, zostaną docenione przez Boga ${ }^{95}$. Zapewniał cesarz adresatów, że dzięki łasce Boga Najwyższego postępujący niegodnie donatyści stracą zwolenników, którzy uświadomią sobie, że są prowadzeni przez nieliczną grupę na wieczne potępienie, a pokutując zechcą naprawić swoje błędy, aby zasłużyć na życie wieczne.

Jak zatem widać, Konstantyn rezygnował z represji, ale nie wycofywał się z bardzo krytycznej oceny donatystów, obciążając ich całkowitą winą za rozłam Kościoła. Cesarz przyznawał się jednocześnie do nieskuteczności prowadzonej przez siebie polityki wobec schizmatyków, toteż w swej bezradności odwoływał się do Boga, w Nim upatrując ostatnią nadzieję na przywrócenie jedności wśród chrześcijan. Ciekawe, że władca ustępował z jednej strony przed uporem donatystów, a więc pośrednio doceniał ich wpływy w Kościele afrykańskim, $z$ drugiej natomiast aż trzykrotnie zwracał uwagę na ich niewielką liczbę ${ }^{96}$. Jak można przypuszczać, Konstantyn rozróżniał wśród nich małą grupę odpowiedzialnych za rozłam i zdecydowanie większą liczebnie grupę ich zwolenników, którzy zostali przez nich zwiedzeni.

\section{Polityka Konstantyna wobec donatystów po zjednoczeniu cesarstwa.} Kiedy władca rozprawił się z Licyniuszem i zjednoczył już całe Imperium Romanum pod swoją władzą, pokrzepiony widomą oznaką przychylności Boga dla swoich poczynań, zamierzał na nowo podjąć sprawę rozłamu Kościoła wywołanego przez donatystów. Pisał o tym w liście adresowanym do Aleksandra, biskupa Aleksandrii i jego prezbitera Ariusza ${ }^{97}$. Na wstępie powołując się na świadectwo Boga, wspomagającego i ochraniającego cesarskie poczynania, Konstantyn wskazywał na dwie kwestie, którymi, jak sądził, winien się zająć z racji sprawowanej przez siebie godności cesarskiej. Pierwsza dotyczyła ustalenia i zebrania razem zasad wiary wspólnych dla wszystkich chrześcijan, druga zaprowadzenia powszechnej zgody między sługami Boga. Cesarz dawał też wyraz swemu przekonaniu, że ewentualne powodzenie podjętych przez niego

95 Por. tamże, CSEL 26, 213: „Nihil ex reciproco reponatur iniuriae; uindictam enim quam deo seruare debemus insipientis est manibus usurpare, maxime cum debeat fides nostra confidere quicquid ab huiusmodi hominum furore patietur martyrii gratia apud deum esse ualiturum".

96 Por. tamże, 14, 21, 52; J. L. Maier, Le dossier du donatisme, t. 1, 241-242.

${ }^{97}$ Por. Epistula Constantini imperatoris ad Alexandrum Alexandrinum et Arium, w: Eusebius, Vita Constantini II 64, 72, PG 20, 1037-1048, lub GCS 7, 67-71. 
działań zaowocuje pomyślnością spraw publicznych. Informował więc, że podjął trud ich realizacji, a dążąc do zaprowadzenia pokoju nie cofnął się nawet przed użyciem siły. Jednak „szaleństwo nie do zniesienia” rozprzestrzeniło się w całej Afryce za sprawą ludzi, którzy „z wyjątkową lekkomyślnością ośmielili się wprowadzać podziały między chrześcijanami" "98. Dlatego też, kiedy tylko cesarz pokonał Licyniusza, wroga cesarstwa i Kościoła, zamierzał wysłać tam kilku biskupów ze wschodniej części cesarstwa, celem przywrócenia jedności między podzielonymi. Myślał ponadto o zorganizowaniu spotkania z biskupami Wschodu, w czym można upatrywać już plany zwołania wielkiego zgromadzenia biskupów. Nie doszły one do skutku w sprawie donatyzmu, bowiem monarcha został poinformowany o jeszcze groźniejszych konfliktach mających miejsce w Kościele egipskim. Z racji na ich rozmiar wymagały one cesarskiej interwencji w pierwszej kolejności. Konstantyn mógł więc tylko ubolewać, że ci, którymi chciał się posłużyć dla uzdrowienia innych, sami wymagali leczenia ${ }^{99}$.

Treść listu skierowanego do Aleksandra i Ariusza dowodzi, że cesarz rezygnując $\mathrm{z}$ represji przeciwko donatystom, nie chciał pogodzić się $\mathrm{z}$ istniejącym rozłamem wśród chrześcijan w Afryce. Zostawszy panem całego imperium zamierzał odwołać się do autorytetu wschodnich biskupów, aby zlikwidować, przy ich udziale, trwającą schizmę. Kiedy jednak został uświadomiony co do konfliktów, jakie targały Kościołem na Wschodzie, postanowił swe plany w tej kwestii przynajmniej odroczyć. Zastanawiające jest jednak, dlaczego biskupi zebrani na soborze w Nicei nie podjęli sprawy donatyzmu. Czyżby władca obawiał się, że może ona nadmiernie pochłonąć uwagę zgromadzonych i przez to utrudnić rozwiązanie problemów pierwszej wagi? A może dostrzegłszy podobieństwo schizmy melecjańskiej, toczącej Kościół w Egipcie, do donatyzmu, nie chciał wspólnego ich rozpatrywania, aby pomiędzy schizmatykami nie zawiązała się jakaś nić porozumienia, albo też nie miała miejsca wymiana doświadczeń między nimi, co mogłoby jedynie pogorszyć sytuację. Konstantyn miał przecież w odniesieniu do donatyzmu poczucie klęski, świadczące o jego bezradności wobec rygorystów, co melecjanie mogliby wykorzystać na swoją korzyść. Ciekawe, że zostali oni potraktowani w Nicei dość oględnie, skupiono się natomiast nad wypracowaniem zasad honorowego ich powrotu na łono Kościoła powszechnego ${ }^{100}$.

Po soborze w Nicei, Konstantyn nie występował już z inicjatywą zażegnania schizmy w Kościele kartagińskim. Edykt, wydany 1 listopada 326 roku, doty-

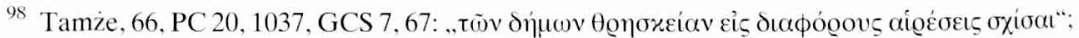
por. Maier, Le dossier du donatisme, t. 1, 244.

${ }^{99}$ Por. Epistula Constantini imperatoris ad Alexandrum Alexandrinum et Arium, w: Eusebius, Vita Constantini II 64-72, PG 20, 1037-1048, GCS 7, 67-71; zob. Maier, Le dossier du donatisme, t. 1, 245.

100 Por. Socrates, HE I 9: T.D.Barnes, Athanasius and Constantius. Theology and Politics in the Constantinian Empire, Cambridge 1993, 17. 
czył donatystów pośrednio, gdyż nie zostali w nim wymienieni. Cesarz wyłączał w nim heretyków i schizmatyków ${ }^{101} \mathrm{z}$ wszelkich wydanych dla kleru przywilejów, które obejmować miały tylko duchownych Kościoła katolickiego. Zobowiązywał ich jednocześnie do ponoszenia stosownych ciężarów na rzecz państwa, tzw. munera ${ }^{102}$. W odniesieniu do donatystów rozporządzenie to nie było jednak skuteczne, o czym świadczy najlepiej cesarski list adresowany do jedenastu biskupów numidyjskich, a datowany 5 lutego 330 roku $^{103}$. Wynika z niego, że schizmatycy obciążenia cywilne składali na barki duchownych katolickich, dopuszczając się nawet zagarnięcia świątyń należących do Kościoła powszechnego, jak o tym świadczy przykład wymienionej w liście bazyliki, zbudowanej przez Konstantyna dla katolików, a zagarniętej przez donatystów.

W liście tym także Konstantyn wyrażał się bardzo niepochlebnie na temat duchownych z pars Donati. Podkreślał, że herezja jak i schizma pochodzą od diabła, który jest początkiem zła. Toteż wszystko, co robią heretycy, czynią za jego namową, będąc przez niego całkowicie zdominowani. Cesarz pytał, jakie dobro może czynić szaleniec, heretyk, bezbożnik, świętokradca, nieprzyjaciel Boga i Kościoła, odwracający się od Najwyższego, aby z powodu błędu znaleźć się w obozie diabła ${ }^{104}$, a wszystkie te epitety kierował pod adresem donatystów. Toteż koniecznym wydawało się monarsze oddzielenie skażonych złem bezbożności od wspólnoty Kościoła, którą określał przy tym mianem „naszej wspólnoty" ${ }^{105}$, a więc z nią się utożsamiał. Dowodzi to, że o żadnym kompromisie $\mathrm{z}$ donatystami Konstantyn wówczas nie myślał. Wprost przeciwnie, doszedł do wniosku, że trwanie z nimi we wspólnocie może przynosić Kościołowi szkodę, dlatego też uznał za lepsze wyłączenie ich z niej, aby powstrzymać szerzenie się zła. Stawiał więc donatystów poza Kościołem, godząc się z istniejącym stanem rzeczy, dzięki czemu jednak przywracał mu tak bardzo przez siebie pożądaną jedność.

Zwracając się natomiast do biskupów katolickich Konstantyn podkreślał, że postępowali sprawiedliwie i mądrze nie naśladując swoich przeciwników wszczynających rozruchy. Chwalił ich cierpliwość i spokój z jakim znosili krzywdy ze strony donatystów, pozostawiając odpłatę samemu Bogu. Podobnie wysoko oceniał ich zachowanie wobec schizmatyków, kiedy ci odebrali im

${ }^{101}$ Po raz pierwszy w ustawodawstwie cesarskim dokonywano tu podziału na heretyków i schizmatyków; zob. A. Dębiński, Ustawodawstwo karne rzymskich cesarzy chrześcijańskich w sprawach religijnych, Lublin 1990, 69-70.

${ }^{102}$ Por. Codex Theodosianus XVI 5, 1.

103 Por. Epistula Constantini imperatoris de basilica catholicis erepta, CSEL 26, 213-216.

${ }^{104}$ Por. tamże, CSEL, 26, 214: „Quid autem boni efficere insanus, perfidus, irreligiosus, profanus, Deo contrarius, ecclesiae sanctae inimicus potest, qui a Deo sancto, uero, iusto, summo atque omnium domino recedens - [...] ad diaboli partem prono errore decurrit?".

105 Por. tamże, CSEL, 26, 214: „Qui malo impiae mentis infecti sunt, necesse est a nostra societate dissideant". 
bazylikę zbudowaną na polecenie cesarza dla katolików. Kierując się duchem pokoju ograniczyli się bowiem jedynie do napomnień prosząc monarchę o ofiarowanie im innego miejsca pod budowę świątyni. Konstantyn polecił natychmiast przyznać im stosowne dobra, a w dodatku zbudować nową bazylikę na koszt państwa i udzielić wszelkiej potrzebnej przy tym pomocy.

Ostatecznie cesarz wyrażał nadzieję, że nadejdzie dzień, kiedy heretycy i schizmatycy zatroszczą się o swoje zbawienie, i choć późno, to jednak „porzucą diabła, aby uciec się do Boga". Wyrażał przekonanie, że gdyby chcieli słuchać jego rozkazów, zostaliby wyzwoleni z wszelkiego zła. Oczekując na ich odmianę, władcy, w jego przekonaniu, nie pozostawało nic innego, jak wypełniać swoje obowiązki i przestrzegać boskich praw szerząc dobro, wystrzegać się błędów i postępować z pomocą miłosierdzia Bożego prawą drogą ${ }^{106}$.

8. Podsumowanie. Jak zatem widać, Konstantyn w toku całego sporu miał ściśle sprecyzowane stanowisko w sprawie donatyzmu. Występując konsekwentnie przeciwko schizmatykom ${ }^{107}$ starał się ich przekonać do uznania wydawanych w ich sprawie wyroków, odwoływał się do coraz to nowych autorytetów, które, jak mógł przypuszczać, były przez donatystów uznawane. Tak więc miał nadzieję, że wyrok, ciągle ten sam, zostanie przez nich w końcu zaakceptowany. Oczekiwał tego od schizmatyków zarówno po niewielkim liczebnie synodzie w Rzymie, jak i po znacznie od niego większym synodzie w Arles, a w końcu spodziewał się, bo takie nadzieje mu dawali, że uznają oni w swojej sprawie autorytet monarszy, toteż sam rozsądził ją w Mediolanie i podobnie jak dotychczas stanął po stronie ich przeciwników. Postępowanie według wspomnianego schematu okazało się jednak nieskuteczne, bowiem donatyści nie chcieli uznać swej winy i nie podporządkowali się żadnemu autorytetowi wydającemu w ich sprawie wyrok.

Na koniec trzeba podkreślić, że Konstantyn miał całkowicie odmienną od donatystów koncepcję Kościoła. Ich dualistyczna idea kłóciła się z cesarską wizją Kościoła zjednoczonego, zapewniającego poprzez swą jedność pomyślność państwu, poddanym i władcy. Toteż od samego początku, kiedy tylko Konstantyn zetknął się z problemem schizmy, ustosunkował się do jej sprawców negatywnie. Stanął po stronie zwolenników Cecyliana, przyznając im prawo do reprezentowania Kościoła katolickiego, a więc powszechnego i prawowitego. W sprawie jedności Kościoła kompromis nie był możliwy, ani ze strony Konstantyna, ani też donatystów. Rezygnując z niej bowiem władca narażałby tym samym sprawy publiczne na wielkie niebezpieczeństwo, a zgadzając się na nią duchowni z pars Donati straciliby swą „czystość”, kalając się

106 Por. tamże. CSEL, 26, 215-216.

107 Donatyści próbowali potem wykazać, że cesarz potępił Cecyliana, zob. Augustinus, Ad Donatistas post collationem 31, 54, ,Biblithèque Augustinienne” 32, 376-378. 
kontaktem z traditores. Kompromis, jaki cesarz był gotów zawrzeć z donatystami, dotyczył jedynie warunków, na których mieliby powrócić na łono Kościoła katolickiego, a więc sprawy drugorzędnej natury.

Konstantyn nie docenił ani determinacji donatystów, ani ich wpływów w społeczności północno-afrykańskiej, kierując swoje oskarżenia o niesubordynację i szaleństwo pod adresem, jak mniemał, małej grupy winowajców. Dlatego też jedność Kościoła zamierzał osiągnąć poprzez ich kapitulację, a w konsekwencji skoncentrował swój wysiłek na tym, aby ją wymusić. Wobec własnej bezsilności Konstantyn odwoływał się do Boga, licząc, ze On wymierzy donatystom sprawiedliwość i w swojej mocy doprowadzi Kościół do jednoś$\mathrm{ci}^{108}$. Konstantyn nie ogłosił jednak wobec donatystów tolerancji, wbrew dość powszechnej opinii panującej na ten temat w literaturze przedmiotu ${ }^{109}$, gdyż nie zalegalizował ich Kościoła, nie uznał go za zgodny z prawnym porządkiem cesarstwa (religio licita) ${ }^{110}$, a jedynie zaniechał prześladowań, prosząc także biskupów katolickich, aby poszli jego śladem. W końcu Konstantyn osiągnął pożądaną jedność Kościoła katolickiego, jednak w sposób całkowicie odmienny od zamierzonego, stawiając donatystów poza jego wspólnotą. Jak pokazały dalsze dzieje donatyzmu, droga do zakończenia schizmy w Kościele w Afryce Północnej była długa i bardzo trudna ${ }^{111}$.

\title{
EST-CE QUE L'EMPEREUR CONSTANTIN LE GRAND A VRAIMENT VOULU FAIRE UN COMPROMIS AVEC LES DONATISTES?
}

\author{
(Résumé)
}

Constantin, au cours du conflit entre Cécilien, l'évêque de Carthage, et les donatistes est toujours resté treès critique envers ces derniers. Il a pris parti pour

${ }^{108}$ L. W. Barnard (Church-State Relations, s. 344) skomentowała to następująco: „However much he might fulminate, the emperor's power was limited in church matters. He could grant privileges and give money, he could hear petitions and disputes, but [...] he could not control ecclesiastical controversy".

109 Zająłem się tym problemem w artykule pt.: Est-ce que l'empereur Constantin Ier le Grand accorda la tolérance à l'égard des donatistes? złożonym w „EOSie”.

${ }^{110}$ Por. T. Kołosowski, Polityka religijna Konstantyna Wielkiego w świetle schizmy donacjańskiej, „Saeculum Christianum” 1(1995), 34.

111 Por. A. Wypustek-Krzyszowski, Kim byli Circumcelliones?, „Meander” 49 (1994), 243 257; T. Kotula, Konferencja 411 r.: Walczqce Kościoły, reprezentanci, reprezentowane ośrodki. W zwiąku z nowym wydaniem „Gesta conlationis Carthaginiensis”, AUWA, 5(1975), 79-88; S. Lancel, Circonstances, préparation et déroulement de la conférence de 411, w: Actes de la conférence de Carthage en 411, SCh 194, 9-106. 
l'évêque et ses alliés de 313 jusqu'à la fin de son règne. Pendant cette même période, l'empereur a tenté de persuader les donatistes d'accepter le jugement désavantageux pour eux. En contrepartie, il leur a offert la possibilité d'être successivement jugés par le concile de Rome, celui d'Arles ainsi que par le tribunal de l'empereur luimême, en espérant ainsi qu'ils accepteraient et se subordonneraient au verdict. Mais cette proposition fut inefficace car les donatistes se prétendaient innocents et de ce fait ils rejetèrent tous les arrêtés à leur encontre. Il faut souligner ici le fait que Constantin avait une conception de l'Église tout à fait différente de celle des donatistes. Leur idée dualiste cadrait mal avec la vision de l'Église unie entretenue par l'empereur. C'est pourquoi le compromis dans l'affaire de l'unité del'Église n'est pas possible: en effet, en rejetant cette l'unité, Constantin risquerait de provoquer une punition de Dieu contre le peuple de l'Empire alors que les donatistes en l'acceptant abandonneraient leur conviction spirituelle car ils considèreraient que leur foi est souillée en ayant des relations avec les traditores. L'empereur était donc seulement prêt à faire un compromis sur les conditions d'entrée des donatistes dans l'Église catholiques. Constatntin n'appréciait ni la déterminaiton ni l'influence des donatistes dans l'Église Nord-Africaine. Le souverain, perplexe en ce qui concerne ce schisme et la désunion de l'Église, a laissé le dâtiment pour les donatistes à Dieu. 